\title{
Predation of the hylid frog Bokermannohyla alvarengai (Bokermann, 1956) by the colubrid snake Chironius flavolineatus (Jan, 1863) in a montane rocky grassland
}

\section{Daniel Cunha Passos ${ }^{1,}{ }^{\text {, }}$ Lucas Henrique Allori Glauss ${ }^{2}$ \& Conrado Aleksander Barbosa Galdino²}

${ }^{1}$ Universidade do Estado do Rio de Janeiro, Instituto de Biologia Roberto Alcântara Gomes, Programa de Pós-Graduação em Ecologia e Evolução. Rio de Janeiro-RJ, CEP 20550-013, Brazil. E-mail: biologodanielpassos@gmail.com ${ }^{2}$ Programa de Pós-Graduação em Zoologia da Pontifícia Universidade Católica de Minas Gerais. Belo Horizonte-MG, CEP 30535-610, Brazil.E-mails: lucas.allori@gmail.com,galdinoc@gmail.com

\begin{abstract}
We reported the predation record of the hylid frog Bokermannohyla alvarengai by the colubrid snake Chironius flavolineatus in a montane rocky grassland in Santana do Riacho municipality, Minas Gerais state, southeastern Brazil. Our findings contribute to the biological knowledge of $B$. alvarengai through identification of one of its natural predators, and of $C$. flavolineatus by adding an anuran species to its diet, data not previously available in the scientific literature.
\end{abstract}

Keywords: diet, predator, prey.

Resumo: Predação da perereca Bokermannohyla alvarengai pela serpente Chironius flavolineatus em um campo rupestre de altitude. Nós relatamos o registro de predação da perereca Bokermannohyla alvarengai pela serpente Chironius flavolineatus em um campo rupestre de altitude no município de Santana do Riacho, estado de Minas Gerais, sudeste do Brasil. Nossos achados contribuem para o conhecimento da biologia de B. alvarengai pela identificação de um de seus predadores naturais, e de $C$. flavolineatus por adicionar uma espécie de anuro à sua dieta, dados até então não disponíveis na literatura científica.

Palavras-chave: dieta, predador, presa.

The record of predatory events allows accurate identification of predators and preys, while provides a key information to understand the complex arrangement of interactions of trophic webs. However, interactions of predation are not easily observed in nature, stressing the importance to provide such naturalistic information. Herein we report, for the first time, the predation of the stone frog Bokermannohyla alvarengai (Bokermann, 1956) by the vine snake Chironius flavolineatus (Jan, 1863).

Bokermannohyla alvarengai (Figure 1) is a large bodied hylid frog (adult snout-vent length ranging from 60.7 to $140.9 \mathrm{~mm}$; LEITE et al., 2011), endemic to the high rocky habitats of the Espin- 
haço Mountain Range, Southeastern Brazil. In spite of the species is listed by International Union for Conservation of Nature as "least concern", one should regard that its habitat is under degradation as a consequence of disorderly recreational tourism, livestocks and non-natural fires (BERTOLUCI \& SILVANO, 2010). The defensive strategies of B. alvarengai has been poorly studied, but it is known that both tadpoles (ETEROVICK et al., 2010) and adults (TOLEDO \& HADDAD, 2009) make use of cryptic behavior to avoid their detection by predators.

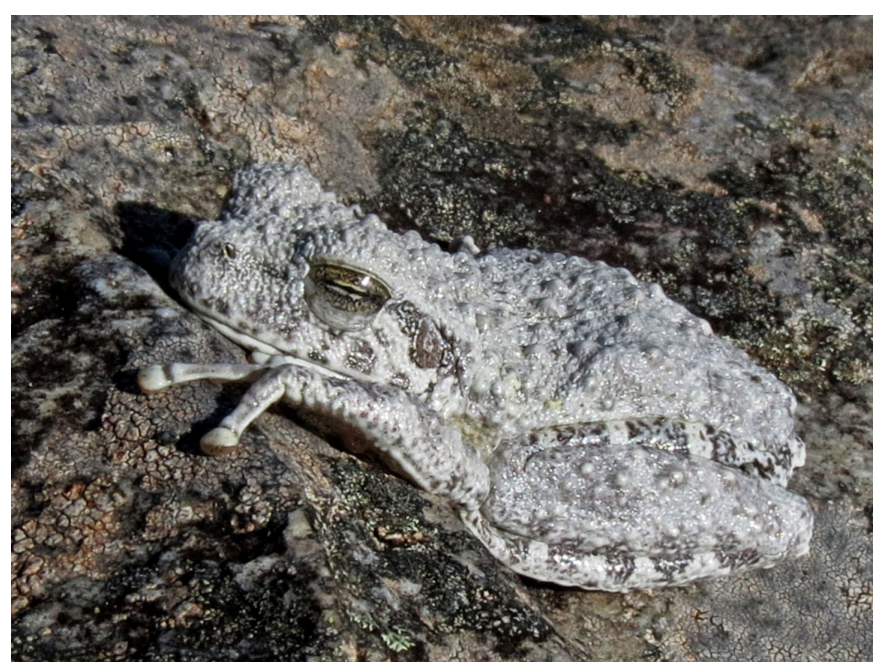

Figure 1. Inactive Bokermannohyla alvarengai exposed on rocky surface during sunlight period in Santana do Riacho municipality, Minas Gerais state, southeastern Brazil. Photograph: Daniel Passos.

Chironius flavolineatus (Figure 2 ) is a medium sized colubrid snake (adult snout-vent length ranging from 507 to $894 \mathrm{~mm}$; PINTO et al., 2008), distributed over savannic formations of South America. Although some information on natural history of Chironius species from Atlantic Forest is available, only few studies has focused on its ecology. This snake feed on anurans, mainly hylid frogs (DIxON et al., 1993, PINTO et al., 2008), and its diet seems to be predominantly composed by Hypsiboas Wagler, 1830 and Scinax Wagler, 1830 species
(Pombal JR., 2007; PINTO et al., 2008).

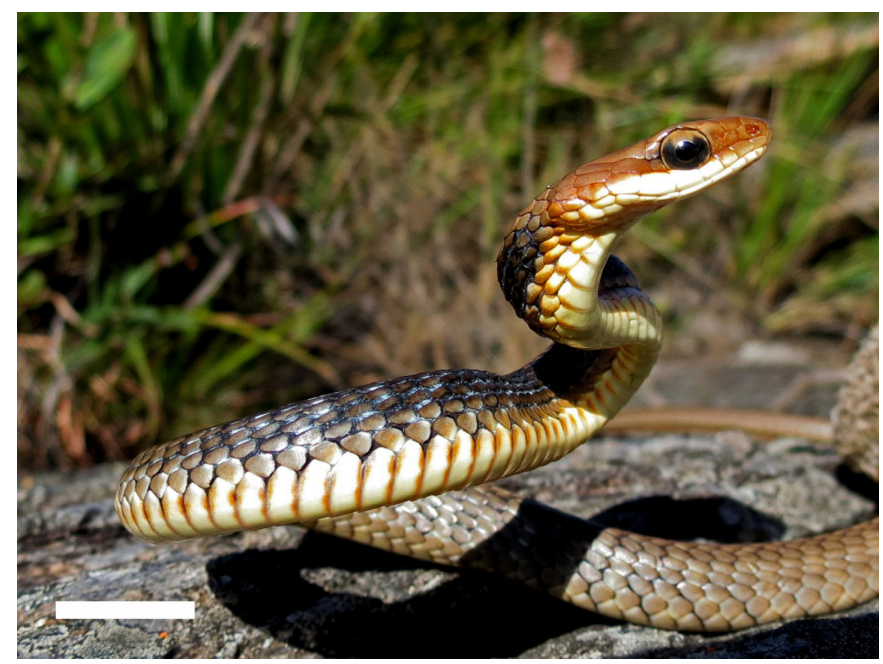

Figure 2. Chironius flavolineatus during defensive display, exhibiting lateral compression of anterior body portion, in Santana do Riacho municipality, Minas Gerais state, southeastern Brazil. Scale bar $=10 \mathrm{~mm}$. Photograph: Daniel Passos.

Our casual sampling took place in the montane rocky outcrop habitat in Serra do Cipó (1917' S, 4335' W, Datum: WGS 1984), Santana do Riacho municipality, Minas Gerais state, Brazil. On 04 July 2013 , at 14:00 h we found an individual of $C$. flavolineatus presenting a marked medial dilatation of its abdomen. We then, captured the snake and induced it to regurgitate by careful pressing its abdomen with anti-peristaltic movements (SHINE, 1995; MEsquitA et al., 2013). The individual C. flavolineatus measured $33.0 \mathrm{~cm}$ for the snout-vent length, $20.0 \mathrm{~cm}$ for the tail length, $13.5 \mathrm{~mm}$ for the head length, $8.6 \mathrm{~mm}$ for the head width, $5.9 \mathrm{~mm}$ for the head height, and had fed on a small $B$. alvarengai with $23.8 \mathrm{~mm}$ of snout-vent length, swallowed headfirst (Figure 3). After the morphometric measurements, the snake was induced to eat the frog again and was released in the site of its capture.

We were able to precisely identify both snake and frog species in view of their diagnostic 


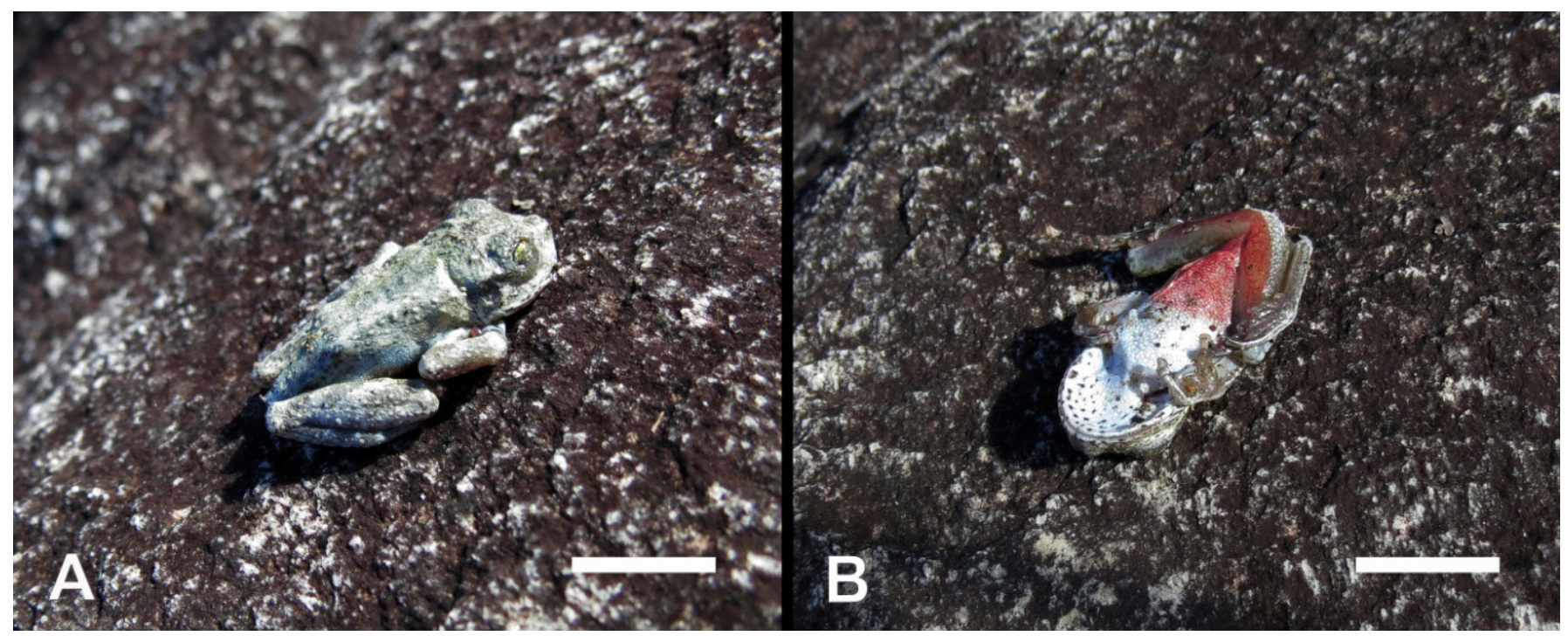

Figure 3. Dorsal (A) and ventral (B) views of Bokermannohyla alvarengai regurgitated by Chironius flavolineatus in Santana do Riacho municipality, Minas Gerais state, southeastern Brazil. Scale bar $=10 \mathrm{~mm}$. Photographs: Daniel Passos.

characters and geographic distribution. Chironius flavolineatus presents a yellow vertebral stripe along the two anterior thirds of the body (DIxON et al., 1993; HAMDAN et al., 2014), and was already recorded to the Serra do Cipó (Assis, 1999). Bokermannohyla alvarengai has a dorsal color pattern that resembles lichens on rocks, with dark brown blotches on a gray background (BOKERMANN, 1956; LEITE et al., 2011), and also has been previously recorded to the Serra do Cipó (MACHADO \& GALDINO, 2005).

Individuals $B$. alvarengai remain motionless thermoregulating unsheltered above the rocks during the daytime period (TATTERSALL et al., 2006), this fact is notable for the juveniles (CABG obs. pers.). Despite $B$. alvarengai is criptic against the rocks with lichens (SAZIMA \& BOKERMANN, 1977), its termoregulatory behavior might exposes individuals to visually oriented predators, as already was confirmed with the predation record by the Chimango Hawk Milvago chimachima (MACHADO \& GALDINO, 2005). The case herein reported pres- ents a chemical oriented predator, $C$. flavolineatus, preying upon $B$. alvarengai during the sunlight period. Our findings expand the knowledge on biology of $B$. alvarengai by the identification of other kind of natural predator for the species.

The diet of $C$. flavolineatus is similar to that from other congeneric species (DIxoN et al., 1993). Hylid frogs are the most common preys of Chironius snakes, for instance, Dendropsophus Fitzinger, 1843 (NASCIMENTO et al., 2013), Itapotihyla Faivovich, Haddad, Garcia, Frost, Campbell \& Wheeler, 2005 (MARques \& Sazima, 2004; Bovo \& SUeIRo, 2012), Hypsiboas (Pombal JR., 2007; OliveIRA, 2008; PINTO et al., 2008; NASCIMENTO et al., 2013), Phyllomedusa Wagler, 1830 (CAStanho, 1996; Bernarde \& ABE, 2010), Scinax (PINTO et al., 2008; HARTMANn et al., 2009; BeRNARDE \& ABE, 2010; NASCIMENTO et al., 2013), and including Bokermannohyla Faivovich, Haddad, Garcia, Frost, Campbell \& Wheeler, 2005 species (RochA et al., 1999). Notwithstanding, the previous case of a Chironius snake preying upon Bokermannohyla (B. circumdata (Cope, 1871)) was 
observed for C. multiventris Schmidt \& Walker, 1943 (RochA et al., 1999). Therefore, our report is the first to record B. alvarengai as prey of $C$. flavolineatus, adding a frog species to consumed preys by this snake.

\section{ACKNOWLEDGEMENTS}

We are grateful to Geraldo Fernandes for permission to work in his property at Serra do Cipó, and to the Instituto Chico Mendes de Conservação da Biodiversidade - ICMBio for collect permit (355411). We also thank Stefania Ventura and Amadeus Václav for helpful comments on manuscript, and Marcela Goulart for assistance in fieldwork. DCP is currently funded by a Doctorate's degree scholarship from Coordenação de Aperfeiçoamento de Pessoal de Nível Superior - CAPES. CABG thanks Fundação de Amparo à Pesquisa do Estado de Minas Gerais - FAPEMIG.

\section{REFERENCES}

AssıS, V.B. 1999. Introdução às serpentes da "Serra do Cipó" (municípios de Santana do Riacho e Jaboticatubas). Bios 7: 69-71.

BERNARDE, P.S. \& ABE A.S. 2010. Hábitos alimentares de serpentes em Espigão do Oeste, Rondônia, Brasil. Biota Neotropica 10: 167-173.

BeRToluCI, J. \& Silvano, D. 2010. Bokermannohyla alvarengai, IUCN Red List of Threatened Species. Available at: <http://www.iucnredlist. org/details/55385/0>. Accessed on: 10 September 2013.

BoKERMANN, W.C.A. 1956. Sobre uma nova espé- cie de Hyla do Estado de Minas Gerais, Brasil (Amphibia, Salientia, Hylidae). Papéis Avulsos do Departamento de Zoologia XII: 357-362.

Bovo, R.P. \& SUEIRO, L.R. 2012. Records of predation on Itapotihyla langsdorffii (Anura: Hylidae) by Chironius bicarinatus (Serpentes: Colubridae) with notes on foraging substrate. Herpetology Notes 5: 291-292.

CAstanho, L.M. 1996. Phyllomedusa distincta (Leaf-Frog). Predation. Herpetological Review 27: 141.

DIXON, J.R.; WIEST, J.A. \& CEI J.M. 1993. Revision of the Neotropical snake genus Chinonius Fitzinger (Serpentes, Colubridae). Monografie XIII. Torino, Museo Regionale di Scienze Naturali, 279 p.

Eterovick, P.C.; Oliveira, F.F.R. \& TATtersall, G.J. 2010. Threatened tadpoles of Bokermannohyla alvarengai (Anura: Hylidae) choose backgrounds that enhance crypsis potential. Biological Journal of the Linnean Society 101: 437-446.

Hamdan, B.; SCALI, S. \& Fernandes, D. S. 2014. On the identity of Chironius flavolineatus (Serpentes: Colubridae). Zootaxa 3794: 134-142.

hartmann, P.A.; Hartmann, M.T. \& Martins, M. 2009. Ecologia e história natural de uma taxocenose de serpentes no Núcleo Santa Virgínia do Parque Estadual da Serra do Mar, no sudeste do Brasil. Biota Neotropica 9: 173-184. 
LeITE, F.S.F.; PezzUTI, T.L. \& DRUMmond, L.O. 2011. A new species of Bokermannohyla from the Espinhaço Range, state of Minas Gerais, Southeastern Brazil. Herpetologica 67: 440-448.

MACHADO, L.L. \& GALDINO, C.A.B. 2005. Hyla alvarengai (NCN). Predation. Herpetological Review 36: 301.

MARqueS, O.A.V. \& SAZIMA, I. 2004. História natural dos répteis da Estação Ecológica Juréia- Itatins, pp. 257-277. In: MARQUes O.A.V. \& DULEBA W. (Eds) Estação Ecológica Juréia-Itatins: Ambiente Físico, Flora e Fauna. Ribeirão Preto, Holos Editora. 384p.

MesquitA, P.C.M.D; PASSOS, D.C.; Borges-NojosA, D.M. \& CECHIN, S.Z. 2013. Ecologia e história natural das serpentes de uma área de Caatinga no nordeste brasileiro. Papéis Avulsos de Zoologia 53: 99-113.

NASCIMENTO, L.P.; SiqueIRA, D.M. \& SANTOS-CostA, M.C. 2013. Diet, reproduction, and sexual dimorphism in the Vine Snake, Chironius fuscus (Serpentes: Colubridae), from Brazilian Amazonia. South American Journal of Herpetology 8: 168-174.

OLIVEIRA, S.V. 2008. Observações do comportamento predatorio de Chironius bicarinatus (Serpentes, Colubridae) em Hypsiboas pulchellus (Anura, Hylidae), Serra do Sudeste, Rio Grande do Sul, Brasil. Biodiversidade Pampeana 6: 1-3.

Pinto, R.R.; FERnANDES, R. \& MARQUes, O.A.V. 2008. Morphology and diet of two sympatric colu- brid snakes, Chironius flavolineatus and Chironius quadricarinatus (Serpentes: Colubridae). Amphibia-Reptilia 29: 149-160.

POMBAL JR, J.P. 2007. Notas sobre predação em uma taxocenose de anfibios anuros no sudeste do Brasil. Revista Brasileira de Zoologia 24: 841843.

ROCHA, C.F.D.; VRCIBRADIC, D. \& VAN SLUYS, M. 1999. Chironius multiventris faveatus (NCN). Prey. Herpetolopical Review 30: 99-100.

SAZIMA, I. \& BokermanN, W.C.A. 1977. Anfíbios da Serra do Cipó, Minas Gerais, Brasil. 3: Observações sobre a biologia de Hyla alvarengai Bok. (Anura, Hylidae). Revista Brasileira de Biologia 37:413-417.

SHINE, R. 1995. Australian Snakes: A Natural History. Ithaca, Cornell University Press, 224 p.

TAtTersall, G.J.; Eterovick, P.C. \& Andrade, D.V. 2006. Tribute to R. G. Boutilier: Skin colour and body temperature changes in basking Bokermannohyla alverengai (Bokermann 1956). The Journal of Experimental Biology 209: 1185-1196.

TOLEDO, L.F. \& HADDAD, C.F.B. 2009. Colors and some morphological traits as defensive mechanisms in anurans. International Journal of Zoology 2009: 1-12. 
